\title{
Conjugated linoleic acid supplementation: lipid content and hepatic histology in healthy Wistar rats
}

\author{
Suplementação com ácido linoleico conjugado: conteúdo de lípides e \\ histologia hepática de ratos Wistar saudáveis
}

\author{
Lilia Ferreira SANTOS-ZAGO ${ }^{1 *}$, Adriana Prais BOTELHO ${ }^{1}$, \\ Admar Costa de OLIVEIRA ${ }^{1}$ (in memoriam), Mário Roberto MARÓSTICA JUNIOR ${ }^{1}$
}

\begin{abstract}
This work aimed to evaluate the effects of the consumption of two commercial conjugated linoleic acid (CLA) mixtures on lipid content and liver histology of healthy rats. The investigation was carried out using thirty rats divided into three groups: $\mathrm{C}$ (control), $\mathrm{AE}$ (AdvantEdge ${ }^{\circ} \mathrm{CLA}$ ), and CO (CLA One ${ }^{\circ}$ ). The concentration of CLA was $2 \%$ of feed consumption, and the animals were supplemented daily for 42 days. The total lipid content of the liver was determined, and the histology of the organ was examined by Transmission Electronic Microscopy. The results of total liver lipid contents did not exhibit significant differences between the groups. With regard to hepatic histology, it was observed that although fat globules were visibly present in higher numbers and bigger size in the CLA groups, the organ histology was considered normal since both cytoplasm and organelles showed integrity. It was concluded that even though liver microscopic images indicated the presence of fat globules in the liver, from a statistical point of view, the supplementation for 42 days did not bring about lipid accumulation, nor did it alter hepatic histology.
\end{abstract}

Keywords: trans fatty acid; liver integrity; oxidative stress; non-alcoholic steatohepatitis.

\begin{abstract}
Resumo
O objetivo do trabalho foi avaliar o efeito da suplementação com duas misturas comerciais de ácido linoleico conjugado (CLA) sobre o conteúdo de lípides e a histologia hepática de ratos saudáveis. Trinta ratos foram divididos em três grupos: C (controle), AE (AdvantEdge ${ }^{\circ} \mathrm{CLA}$ ) e CO (CLA One ${ }^{\oplus}$ ). A concentração de CLA foi de $2 \%$ em relação ao consumo diário de dieta, e os animais foram suplementados diariamente durante 42 dias. O conteúdo de lípides totais foi determinado e a histologia hepática foi examinada por meio de Microscopia Eletrônica de Transmissão. Não houve diferença significativa nos resultados de conteúdo de lípides hepáticos entre os grupos. Quanto à histologia hepática, embora tenha sido observada a presença de glóbulos de gordura em maior número e tamanho nos grupos suplementados com CLA, a histologia do órgão apresentou-se normal, visto que citoplasma e organelas estavam íntegros. Concluiu-se que não houve acúmulo de lípides nem alteração da histologia hepática após 42 dias de suplementação com CLA.
\end{abstract}

Palavras-chave: ácido graxo trans; integridade hepática; estresse oxidativo; esteato-hepatite não alcoólica.

\section{Introduction}

Conjugated linoleic acid (CLA) is the name given to a set of geometrical and position isomers of the octadecadienoic acid with predominance (70-80\%) of the cis-9, trans-11 and trans-10, and cis-12 isomers (PARODI, 1977; OUSTROWSKA et al., 2004). CLA can be synthesized by ruminants by biohydrogenation of dietary unsaturated fatty acids or endogenously in the mammary glands. Since the late 1970s, when CLA was discovered, its consumption has been associated with physiological effects such as body fat reduction, arteriosclerosis reduction, prevention and treatment of type 2 diabetes mellitus, enhancement of bone mineralization, immune system modulation, antithrombogenic action, and antioxidant action (SALAS-SALVADÓ; MARQUEZSANDOVAL; BULLÓ, 2006; PARIZA et al., 1979; PARIZA; HARGRAVES, 1985). However, there has also been significant investigation about the possibility of adverse effects of CLA consumption, particularly regarding increased susceptibility to biological lipid oxidation, resistance to insulin, and lipid accumulation in the liver; the latter can be one of the causes of non-alcoholic steatosis and steatohepatitis (YAMASAKI et al., 2000; BASU; SMEDMAN; VESSBY, 2000; RISÉRUS et al., 2004; CHOI; SONG, 2005; BROWN; MCINTOSH, 2003). This hypothesis was raised because CLA can act as a ligand of peroxisome proliferator activated receptors (PPAR) and inhibit their gene expression, particularly PPAR $\gamma$ (BELURY et al., 2002; KANG et al., 2003). Studies show that inhibition of PPAR $\gamma$ and also of PPAR $\alpha$ is related to the possibility of development of non-alcoholic steatohepatitis. Furthermore, some authors reported, based on biological assays with different experimental models, that CLA can lead to changes including not only lipid accumulation, but also significant lesions in liver cell organelles

Recebido para publicação em 19/2/2009

Aceito para publicação em 31/10/2009 (004074)

${ }^{1}$ Laboratório de Lípides, Departamento de Alimentos e Nutrição, Faculdade de Engenharia de Alimentos, Universidade Estadual de Campinas - UNICAMP,

Rua Monteiro Lobato, 80, Cidade Universitária Zeferino Vaz, Barão Geraldo, CP 6121, CEP 13083-862, Campinas - SP, Brasil, E-mail: lzago@fea.unicamp.br

${ }^{*}$ A quem a correspondência deve ser enviada 
visible by transmission electron microscopy (TEM) (BELURY; KEMPA-STECZKO, 1997; CHERIAN et al., 2002). Although CLA is naturally found in foods such as ruminant meat and dairy foods, the amounts are very small, and for that reason CLA is mainly consumed in the form of supplements. There are numerous commercial CLA mixtures in the market with different isomer proportions (but always with a predominance of cis-9, trans- 11 and trans- 10 , and cis- 12 isomers) and synthesis methods, which could influence physiological effects. The aim of this work was to assess the differences between two commercial CLA dietary supplementation in terms total lipid content of the liver and liver histology of the liver of healthy Wistar rats.

\section{Materials and methods}

\subsection{Supplements}

The investigated supplements were linoleic acid Sigma (code L 1376), the commercial conjugated linoleic acid mixtures AdvantEdge ${ }^{\odot}$ CLA (EAS ${ }^{\mathrm{TM}}$, Golden, CO, USA), and CLA One ${ }^{\oplus}$ Free Fatty Acid Oil 1CLA1-FFBL-KG (Pharmanutrients, Gurnee, IL, USA). The isomers' composition of conjugated linoleic acid supplements was determined by gas chromatography (SEHAT et al., 1998; SANTOS-ZAGO; BOTELHO; OLIVEIRA, 2007).

\subsection{Animals and diets}

The biological assays were conducted with albino male healthy recently-weaned Wistar rats aged 21 to 23 days, with mean weight $59.7 \pm 5.84 \mathrm{~g}$, obtained from the Multidisciplinary Center for Biological Investigation, State University of Campinas. During the assay, the animals remained in individual stainless steel growth cages, and received water and feed ad libitum. Temperature and humidity were kept in the range of 22 e $23{ }^{\circ} \mathrm{C}$ and $60-70 \%$, respectively, and a 12 -hour light/dark cycle. This procedure was approved by the Ethics Commission on Animal Experimentation (CEEA - IB/Unicamp), Protocol no. 564-1. The diet, AIN93G, was prepared according to the American Society for Nutrition (REEVES; NIELSEN; FAHEY, 1993), with protein concentration of $12 \%$ (Table 1) (GOENA et al., 1989).

\subsection{Experimental design}

Thirty rats remained in a period of adjustment for 7 days receiving water and the respective diets ad libitum. After this period the animals were divided into 3 groups in order to achieve body weight homogeneity within and among the groups. Group C (control) received linoleic acid; group AE received AdvantEdge ${ }^{\oplus}$ CLA; and group CO received CLA One. The supplement concentration was $2 \%$ of daily feed consumption. Animals were supplemented daily for 6 weeks. Body weight and feed consumption were determined every two days. At the end of the study, part of the liver left lobe was excised, weighed, frozen in liquid nitrogen, and stored at $-80^{\circ} \mathrm{C}$ before lyophilization for determination of total lipid content.
Table 1. Composition of experimental diet.

\begin{tabular}{lr}
\hline \multicolumn{1}{c}{ Ingredients } & g.kg-1 $^{-1}$ \\
\hline Cornstarch & 430.796 \\
Dextrinized cornstarch & 143.060 \\
Casein (81.5\% protein) & 147.230 \\
Sucrose & 108.370 \\
Soybean oil & 70.000 \\
Fiber & 50.000 \\
Mineral mix & 35.000 \\
Vitamin mix & 10.000 \\
L-cystine & 3.000 \\
Choline bitartrate & 2.500 \\
Tert-butylhydroquinone & 0.014 \\
\hline
\end{tabular}

\subsection{Supplementation}

Animals were supplemented by orogastric intubation with disposable $1 \mathrm{~mL}$ syringes and gavage needles. The amount of supplement administered was computed every other day according to the average daily feed consumption of each group, i.e., supplementation followed the normal feed ingestion. The quantity, in milliliters, of each supplement was calculated considering the density of the supplements (linoleic acid: 0.90 g.mL ${ }^{-1}$; AdvantEdge ${ }^{\circ} \mathrm{CLA}: 0.87$ g. $\mathrm{mL}^{-1}$; and CLA One ${ }^{\oplus}$ : 0.77 g. $\mathrm{ml}^{-1}$ ) and ranged from 0.25 to $0.49 \mathrm{~mL}$. During the experimental procedures, the supplements were kept away from light to avoid oxidation. The rats were removed group by group from the experiment room, placed in plastic boxes, and taken to the supplementation room. This procedure was repeated daily at $02 \mathrm{PM}$ since rodent have nocturnal habits and were less satiated at that time.

\subsection{Determination of total hepatic lipid content}

The determination of total hepatic lipid contents was done by the method of Bligh and Dyer (1959) with some modifications due to sample peculiarities. About $1 \mathrm{~g}$ of lyophilized sample was homogenized in $5 \mathrm{~mL}$ of chloroform, $10 \mathrm{~mL}$ of methanol, and $4 \mathrm{~mL}$ of water followed by continual rotary agitation for 30 minutes. Next, $5 \mathrm{~mL}$ of chloroform and $5 \mathrm{~mL}$ of $1.5 \%$ sodium sulphate aqueous solution were added, and the sample was vigorously and continually shaken for 2 minutes. After dilution and complete separation of phases, the lower chloroform phase containing the lipids was filtered in quantitative paper filter to obtain a clear solution. From this phase, $2 \mathrm{~mL}$ were transferred (determination done in duplicate) to a previously weighed Petri dish, which was placed into an oven at $100^{\circ} \mathrm{C}$ for solvent evaporation. After cooling in a desiccator, the dishes were weighed, and the total lipid percentage was calculated.

\subsection{Sample preparation for examination by transmission electronic microscopy}

Part of the liver left lobe of three rats per group $(0.3 \times 0.5 \mathrm{~mm})$, randomly chosen, was excised and subjected to the protocols of fixing, post-fixing, dehydration, infiltration, inclusion, and contrasting by transmission electronic microscopy (TEM) 
according to Yamasaki et al. (2000) with some adaptations based on the protocols of Haddad et al. (1998). After extraction, the samples were immediately fixed in a glutaraldehyde solution (2\%) in cacodylate buffer $(0.1 \mathrm{M}, \mathrm{pH} 7.3)$ for 2 hours at $4{ }^{\circ} \mathrm{C}$. After this, the samples were washed in cacodylate buffer ( 3 times, for 10 minutes each) and subjected to the post-fixing procedure, remaining in osmium tetroxide in cacodylate buffer $(0.2 \mathrm{M}, \mathrm{pH}$ 7.3) for 2 extra hours at $4{ }^{\circ} \mathrm{C}$. Before beginning the ethanol series dehydration, the samples underwent postfixation, in which they were washed 3 times for 10 minutes in a physiological solution added with sucrose $(17.8 \%)$ and remained in an aqueous solution of uranyl acetate $(0.5 \%)$ added with sucrose $(13.3 \%)$ for 12 hours.

For the dehydration process, the samples were washed 3 times for 15 minutes in an ethanol series of 50\%, 70\%, 90\%, 95\%, and $100 \%$ ending with two 15 -minute washings in propylene oxide. The samples were then subjected to the procedures of infiltration and inclusion. After their inclusion in resin, the samples were sent to the Electronic Microscopy Laboratory of the Biology Institute of the State University of Campinas for ultrathin cuts (70 $\mathrm{nm}$ thickness), which were placed in copper meshes (3 mm / 200 mesh). The samples were contrasted in uranyl acetate solution (5\%) in water for 20 minutes and in lead citrate solution (2.66 g of lead nitrate dissolved in $60 \mathrm{~mL}$ of water, $3.52 \mathrm{~g}$ of sodium citrate and $32 \mathrm{~mL}$ of sodium hydroxide $1 \mathrm{~N}$ ) for 5 minutes. After contrasting, the samples were examined in a transmission electronic microscope (LEO 906 Zeiss).

\subsection{Statistical analysis}

The results were expressed as means \pm standard deviation. The data were analyzed statistically by ANOVA to test the effect of CLA mixtures. The effect of supplementation time on feed consumption and growth was also examined. The Tukey test was used to test the differences among the groups. Differences were considered significant at $\mathrm{p}<0.05$. The software used for all tests was Statistical Analysis System (2003).

\section{Results}

The total cis-9, trans-11 CLA and trans-10, cis-12 CLA of the commercial mixtures was $79.27 \%$ and $73.08 \%$ for AdvantEdge ${ }^{\oplus}$ CLA and CLA One ${ }^{\bowtie}$, respectively. The data of feed consumption, initial and final body weight and feed efficiency, are shown in Table 2 and Figure 1. Differences were found only between groups $\mathrm{C}$ and $\mathrm{AE}(\mathrm{p} \leq 0.05)$.

The results of the liver weight/body weight ratio were expressed in Table 3.There was no significant difference $(p>0.05)$ between the control group and CLA supplemented groups. With regard to total hepatic lipids, no significant difference $(\mathrm{p}>0.05)$ was observed between the control group and the groups receiving AdvantEdge ${ }^{\circledast}$ CLA or CLA One ${ }^{\circledast}$

Figure $2 \mathrm{a}, \mathrm{b}$ and $\mathrm{c}$ illustrate TEM liver images of animals that received supplementation of linoleic acid (group C), AdvantEdge $^{\circledast}$ CLA (group AE), and CLA One ${ }^{\circledast}$ (group CO) (All images were analysed by technical staff from Laboratory of Food Microscopy (College of Food Engeneering) and from Electronic Microscopy Laboratory (Institute of Biology), both of the State University of Campinas). Those pictures show a large amount of small and long mitochondria spread between the rough and smooth endoplasmic reticulum in the central region of the cell and large and round-sahped mithocondria near the cell peripheral region, which characterizes cell integrity (SATO, 2004).

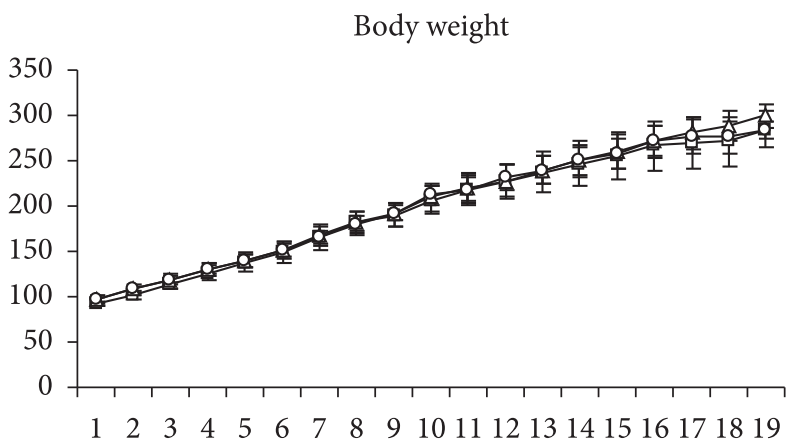

Food consumption

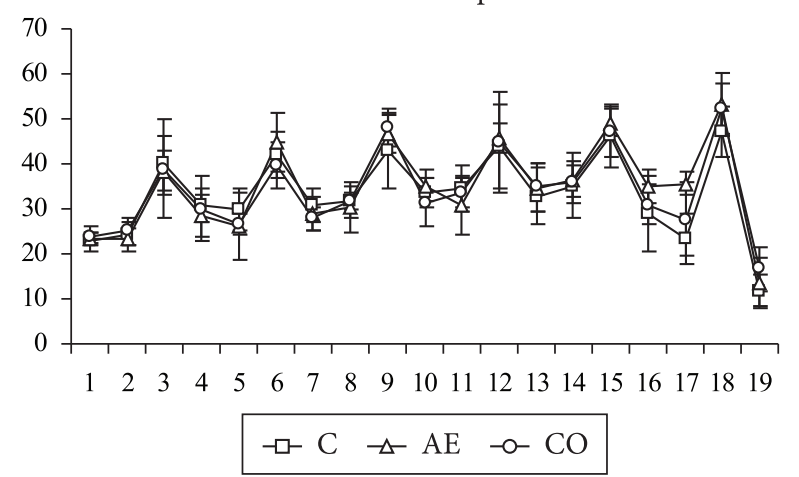

Figure 1. Body weight (g) and food consumption (g/rat/period) in control and experimental groups $(\mathrm{n}=10)$. Upper figure represents mean weight values $(\mathrm{g})$; lower figure represents mean food consumption (g) in a period of two days during the period that animals remained in individual growth cages (38 days). C: control group; AE: group supplemented with AdvantEdge ${ }^{\oplus}$ CLA; CO: group supplemented with $\mathrm{One}^{\otimes} \mathrm{CLA}$; ${ }^{*}$ statistical difference between group $\mathrm{AE}$ and group $\mathrm{C}$ and $\mathrm{CO}$ according to Tukey test $(\mathrm{p} \leq 0.05)$.

Table 2. Mean values \pm standard deviation $(n=10)$ of feed consumption, initial and final body weight and feed efficiency of experimental and control groups over the six week intervention period.

\begin{tabular}{ccccc}
\hline Groups & Consumption $(\mathrm{g})$ & Initial body weight $(\mathrm{g})$ & Final body weight $(\mathrm{g})$ & Feed efficiency \\
\hline C & $631.2 \pm 48.7^{\mathrm{a}}$ & $91.4 \pm 2.3^{\mathrm{a}}$ & $284.0 \pm 20.2^{\mathrm{a}}$ & $0.30 \pm 0.02^{\mathrm{a}}$ \\
AE & $645.7 \pm 27.6^{\mathrm{b}}$ & $96.3 \pm 5.5^{\mathrm{a}}$ & $299.8 \pm 13.1^{\mathrm{a}}$ & $0.31 \pm 0.01^{\mathrm{a}}$ \\
CO & $621.9 \pm 30.9^{\mathrm{a}}$ & $96.7 \pm 3.6^{\mathrm{a}}$ & $283.7 \pm 9.6^{\mathrm{a}}$ & $0.30 \pm 0.01^{\mathrm{a}}$ \\
\hline
\end{tabular}

Values not sharing similar letter in the same column are different $(\mathrm{p} \leq 0.05)$ in the Tukey test. C: control; AE: group that received AdvantEdge ${ }^{\circ}$ CLA; CO: group that received CLA One ${ }^{\oplus}$. 
Table 3. Mean values \pm standard deviation $(n=10)$ of liver lipid content and weight and liver weight: body weight rate of control and experimental groups.

\begin{tabular}{cccc}
\hline Groups & Lipid content \% & Liver weight g & Liver weight: body weight rate \\
\hline C & $23.93 \pm 3.64^{\mathrm{a}}$ & $2.5 \pm 0.4^{\mathrm{a}}$ & $0.023 \pm 0.03^{\mathrm{a}}$ \\
AE & $22.19 \pm 2.05^{\mathrm{a}}$ & $2.8 \pm 0.5^{\mathrm{a}}$ & $0.025 \pm 0.03^{\mathrm{a}}$ \\
CO & $21.16 \pm 0.90^{\mathrm{a}}$ & $2.6 \pm 0.3^{\mathrm{a}}$ & $0.024 \pm 0.02^{\mathrm{a}}$ \\
\hline
\end{tabular}

Values with different letters in the same column indicate significant difference $(\mathrm{p}<0.05)$ in the Tukey test values expressed on a dry basis; lyophilized sample. C: control; AE: group that received AdvantEdge ${ }^{\circ}$ CLA; CO: group that received CLA One ${ }^{\circ}$.

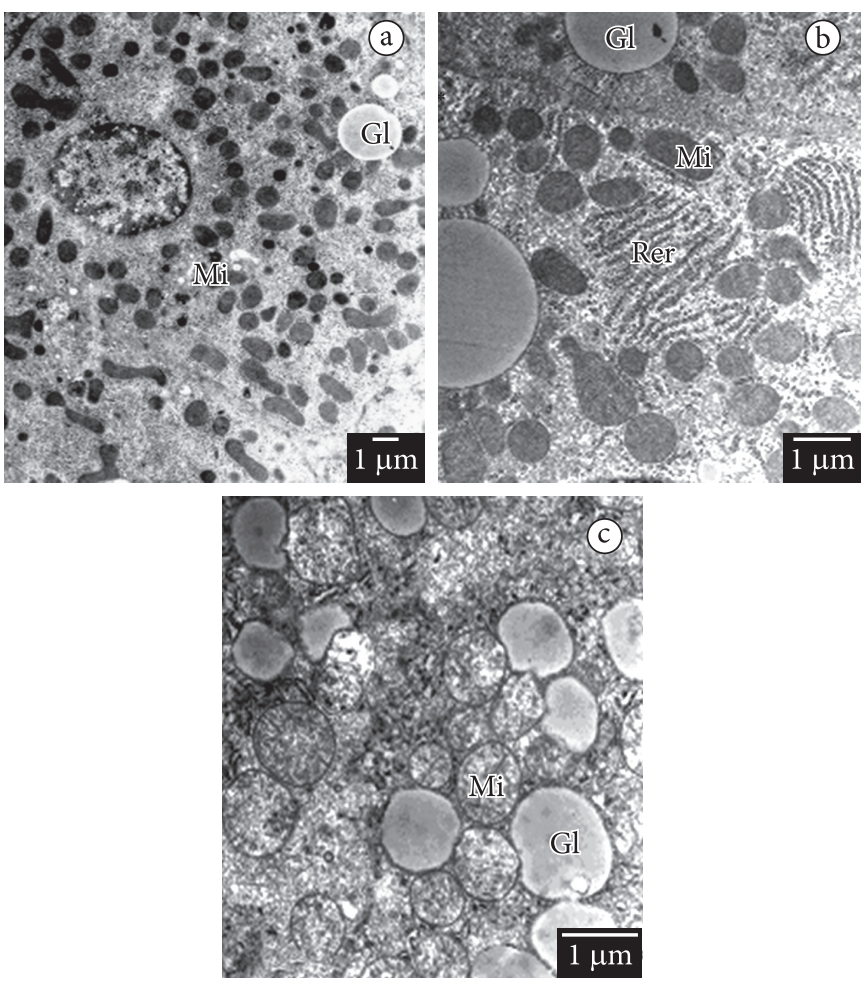

Figure 2. a)Hepatic Transmission Electron Microscopy (TEM) images of rats that received supplementation with linoleic acid; b) AdvantEdge ${ }^{\oplus}$ CLA; and c) CLA One. Mi (mitochondria); Rer (rough endoplasmic reticulum); Gl (lipid globule).

\section{Discussion}

With respect to the feed consumption and weight gain of the rats during the supplementation period, it can be said that even though small differences between some of the groups were observed, the animals growth was normal. These feed consumption differences are a consequence of a correction in the supplementation amount for both, the control and CLA mixtures). The daily concentration of CLA supplementation was based on the daily feed consumption, i.e. the heavier the diet consumption, the heavier the supplement consumption. The lipidic origin of the supplement produced satiety, and therefore the diet consumption reduced and consequently the supplement consumption also reduced.

Diet consumption increase $\rightarrow$ supplement consumption increase; Diet consumption reduction (due to satiety) $\rightarrow$ supplement consumption reduction.
This occurred cyclically throughout the assay, but it is important to note that these oscillations did not compromise animal growth.

As for the total hepatic lipid content, in the present work, no difference was found among all groups studied $(p>0.05)$. However, some studies reported lipid accumulation in the liver as a consequence of CLA supplementation. Studies on the influence of CLA on total hepatic lipid content have reported that this fatty acid accrue in the liver of experimental models, and this may result in the development of steatosis and non-alcoholic steatohepatitis (BELURY; KEMPA-STECZKO, 1997; CHERIAN et al., 2002). Non-alcoholic steatohepatitis is so called when clinical and histopathological characteristics indicate steatohepatitis, but alcohol consumption has been ruled out as the cause. The designation was introduced in the 1980s by Ludwig et al. (1980), but currently the preferred name is non-alcoholic fatty liver disease, which includes steatosis and steatosis accompanied by hepatitis (HOEK, 2004). The etiopathogenesis of this kind of hepatic lipid disease is related to the presence of a number of pathologic conditions such as obesity, diabetes, hyperlipidaemia, and oxidative stress. The latter has a double influence: direct, when oxidative stress itself causes liver damage; and indirect, when it activates an inflammatory response leading to liver damage (BRUNT, 2001; CHITURI; FARREL, 2001; VIDELA et al., 2004; ADAMS; ANGULO; LINDOR, 2005).

Some researchers attempted to explain the appearance of steatosis and steatohepatitis by the determination of the expression of $\alpha$ and $\gamma$ peroxisome proliferator activated receptors (PPAR $\alpha$ and PPAR $\gamma$ ). There is a hypothesis that CLA acts as a ligand of PPAR, especially PPAR a and PPAR $\gamma$ (BELURY et al., 2002; KANG et al., 2003; MOYA-CAMARENA et al., 1999). If this is indeed the case, CLA supplementation may be efficient in hepatic lipid disease prevention, and may act as an adjuvant in its treatment. Many physiological properties of CLA are explained by the inhibition or activation of the expression of these transcription factors. One of the earliest studies demonstrating that CLA activates PPAR was reported by Moya-Camarena et al. (1999). The results showed that CLA increases PPAR a expression, especially the cis-9 and trans-11 isomer. In 2002, Belury et al. (2002) stated that supplementation with CLA isomer mixture in kidney cells of monkeys stimulated PPAR $\gamma$ activation. The activation of PPAR $\alpha$ and $\gamma$ may be related to the increase in long and very long chain fatty acid oxidation. This is one of the explanations, for instance, of the effects of CLA on lipid profile since the increase in fatty acid oxidation caused by the increased expression of PPAR a (AKBIYIK et al., 2004) could 
result in a reduction in blood concentration of lipids such as triacylglycerols.

In view of the above, CLA supplementation could be proposed as an adjuvant in the treatment of steatohepatitis since CLA can act as a ligand of intracellular receptors. However, studies that investigated the possibility of an inhibition of the expression of genes of these PPARs by CLA must also be taken into account. The study by Granlund et al. (2003) sought evidence to explain the effect of CLA in body fat reduction and found results that suggest PPAR $\gamma$ expression inhibition, caused chiefly by the trans-10, cis- 12 isomer. The authors stated that these results could explain the mechanism by which CLA reduces body fat since PPAR $\gamma$ expressed exclusively in adipocytes is related to the differentiation process of these cells.

In order to study the modulation of hepatic lipid composition by CLA, Belury and Kempa-Steczko (1997) supplemented rats daily with different concentrations of CLA in the range of 0 to $1.5 \%$ of daily feed consumption for 42 days. The authors found values of total hepatic lipid content significantly higher in groups receiving supplementation; the highest values were for rats receiving $1.5 \%$ of CLA. In a later study, Yamasaki et al. (2000) stated that in addition to increasing lipid autoxidation, CLA also brings about hepatic histology changes. The authors observed, by using transmission electronic microscopy, an accumulation of lipid, easily identified in the liver of rats supplemented with $2 \%$ of CLA daily for 21 days in comparison to the control group that did not receive this supplement. Considering the isomer-specific effects of CLA, it is important to discuss that CLA potential role in lipid accumulation in the liver could be isomer dependent. The trans-10, cis-12 CLA seems to be the responsible for lipid accumulation in the rodent liver as a result of hyperinsulinemia, whereas cis-9, trans- 11 did not shown this effect (CLEMENT et al., 2002).

It is important to include hepatic histological monitoring in CLA experimental protocols as a tool to identify signs that the organ is compromised as a result of CLA supplementation since there are indications that it might influence gene expression of nuclear transcription factors - PPAR $\alpha$ and PPAR $\gamma$ - and thus lead to the development of steatohepatitis.

In the present research, TEM images showed that although there were a larger number of fat globules in the liver of the rats that received CLA, this increase was not sufficient to cause damage to the organ since both cytoplasm and cell organelles remained undamaged. A similar conclusion was reached in the study mentioned above (YAMASAKI et al., 2000), which did not report any change in number or histology of cell organelles either. In contrast, Cherian et al. ( 2002) supplemented white crest Leghorn chicken with different concentrations of CLA (0 / 0.5 / 1.0 / 2.0\%) for 42 days and observed a significant hepatic lipid accumulation as well as abnormalities resulting from this, manifested by sinusoidal fibrin deposits and cell necrosis, especially in the group of birds that received the highest CLA concentration. Another study by the same author and with the same experimental model (CHERIAN; GOEGER, 2004) also showed fat deposition, significant negative histological changes (dilated sinusoids, intrasinusoidal fibrin deposition, lymphocyte aggregates, and cell necrosis) in the liver of animals that consumed a diet with $1 \%$ of CLA for 80 days. More recently, Macarulla et al. (2005) investigated the effect of the trans-10, cis-12 and cis-9, and trans-11 isomers on hepatic histology of hamsters and did not find abnormalities in the organs after the animals consumed a diet supplemented with $0.5 \%$ of CLA isomers for 6 weeks.

Some researches assessed liver steatosis by monitoring the concentration of aminotransferases (LAVINE, 2000; ELITSUR et al., 2005); however, the histology assessment is the gold standard to evaluate the therapeutic efficacy against hepatic lipid disease of non-alcoholic origin. Akyüz et al. (2005) discussed the use of histology in order to assess the response of NASH to any therapy since they found no correlation between aminotransferase concentration and histology. In view of the above, enzymology could be a significant tool for the identification follow-up of non-alcoholic hepatic disease regression, but hepatic histology monitoring is necessary in this process since it can lead to different responses especially concerning the efficacy of therapies used to reverse the condition.

\section{Conclusions}

After examining the results, it was concluded that the groups supplemented with conjugated linoleic acid did not display higher hepatic lipid content than the control group $(p>0.05)$. Although mean values did not indicate hepatic lipid accumulation, it was clearly observed that there was an increase of fat globules in the liver of rats that received CLA supplementation. However, this increase did not alter the histological pattern of cell organelles.

\section{Acknowledgements}

The authors are grateful for the financial support provided by FAPESP, The State of São Paulo Research Foundation (Process 2003/07648-4); The authors also gratefully acknowledge the following colleagues: BOTELHO, A.P (CNPq, The National Council for Scientific and Technological Development ) and Mrs Yara Fagnani Honório (Laboratory of Food Microscopy) for their contributions and expertise; the trainee staff of the Lipids Laboratory both of the College of Food Engineering of the State University of Campinas, for technical assistance; and the technical staff of the Electronic Microscopy Laboratory of the Biology Institute of the State University of Campinas, for technical assistance.

\section{References}

ADAMS, L. A.; ANGULO, P.; LINDOR, K. D. Nonalcoholic fatty liver disease. Canadian Medical Association Journal, v. 172, n. 7, p. 899-905, 2005.

AKBIYIK, F. et al. Ligand-induced expression of peroxissome proliferators activated receptor $\alpha$ and activation of fatty oxidation enzymes in fatty liver. European Journal of Clinical Investigation, v. 34, n. 6, p. 429-435, 2004.

AKYÜZ, F. et al. What is the best indicator for evaluating treatment response in nonalcoholic fatty liver disease: histology or aminotransferase levels? Journal of Gastroenterology and Hepatology, v. 20, n. 1, p. 167-168, 2005. 
BASU, S.; SMEDMAN, A.; VESSBY, B. Conjugated linoleic acid induces lipid peroxidation in humans. FEBS Letters, v. 468, n. 1, p. 33-36, 2000.

BELURY, M. A. et al. Conjugated linoleic acid is na activator and ligand for peroxissome proliferator-activated receptor-gama (PPAR $\gamma$ ). Nutrition Research, v. 22, n. 7 , p. 817-824, 2002.

BELURY, M. A.; KEMPA-STECZKO, A. Conjugated linoleic acid modulates hepatic lipid composition in mice. Lipids, v. 32, n. 2, p. 199-204, 1997.

BLIGH, E. G.; DYER, W. J. A rapid method of total lipid extration and purification. Canadian Journal of Biochemistry and Physiology, v. 37, n. 8 , p. $911-917,1959$.

BROWN, J. M.; MCINTOSH, M. K. Conjugated linoleic acid in humans: Regulation of adiposity and insulin sensitivity. Journal of Nutrition, v. 133, n. 10, p. 3041-3046, 2003.

BRUNT, E. M. Nonalcoholic steatohepatitis: definition and pathology. Seminars in Liver Disease, v. 21, n. 1, p. 3-16, 2001.

CHERIAN, G et al. Dietary CLA alters yolk and tissue FA composition and hepatic histopathology of laying hens. Lipids, v. 37, n. 8, p. 751-757, 2002.

CHERIAN, G.; GOEGER, M. P. Hepatic lipid characteristics and histopathology of laying hens fed CLA or n-3 fatty acids. Lipids, v. 39, n. 1, p. 31-36, 2004

CHITURI, S.; FARREL, G. C. Etiopathogenesis of nonalcoholic steatohepatitis. Seminars in Liver Disease, v. 21, n. 1, p. 27-41, 2001.

CHOI, J. S.; SONG, J. Conjugated linoleic acid, obesity, and insulin resistance: waiting for the day of liberation from chronic disease. Nutrition, v. 21, n. 11, p. 1170-1172, 2005.

CLEMENT, L. et al. Dietary trans-10, cis-12 conjugated linoleic acid induces hyperinsulinemia and fatty liver in the mouse. Journal Lipid Research, v. 43, n. 9, p. 1400-1409, 2002.

ELITSUR, Y. et al. Treatment for NASH:the value of histology. Journal Gastroenterology: A Journal of Clinical Gastroenterology, v. 100, n. 1, p. 250-251, 2005.

GOENA, M. et al. Effect of the raw legume Vicia ervilha on muscle and liver protein metabolism in growing rats. Revista Española de Fisiologia, v. 45, Supplement, p. 55-60, 1989.

GRANLUND, L. et al. Trans10, cis12-conjugated linoleic acid prevents triacylglycerol accumulation in adipocytes by acting as a PPAR $\gamma$ modulator. Journal of Lipid Research, v. 44, n. 8, p. 1441-1452, 2003.

HADDAD, A. et al. Técnicas básicas de microscopia eletrônica aplicadas às ciências biológicas. Rio de Janeiro: Sociedade Brasileira de Microscopia, 1998.

HOEK, B. V. Non-alcoholic fatty liver disease: a brief review. Scandinavian Journal of Gastroenterology, v. 39, Supplement, p. 56-59, 2004.

KANG, K. et al. Trans-10, cis-12 CLA inhibits differentiation of 3T3-L1 adipocytes and decreases PPAR $\gamma$ expression. Biochemical and Biophysical Research Communications, v. 303, n. 3, p. 795-799, 2003.

LAVINE, J. E. Vitamin E treatment of nonalcoholic steatohepatitis in children: a pilot study. Journal of Pediatrics, v. 136, n. 6, p. 734-738, 2000 .

LUDWIG, J. et al. Nonalcoholic steatohepatitis. Mayo Clinic experience with a hitherto unnamed disease. Mayo Clinic Procedings, v. 55, n. 7 , p. $434-8,1980$.
MACARULLA, M. T. et al. Effects of conjugated linoleic acid on liver composition and fatty acid oxidation are isomer-dependent in hamster. Nutrition, v. 21, n. 4, p. 512-519, 2005.

MOYA-CAMARENA, S. Y. et al. Conjugated linoleic acid is a potent naturally occurring ligand and activator of PPARa. Journal Lipid Research, v. 40, n. 8, p. 1426-1433, 1999.

OUSTROWSKA, E. et al. Milk conjugated linoleic and trans-vaccenic acids are highest in Spring in grazing cows. Asian Pacific Journal of Clinical Nutrition, v. 13, Supplement, p. S53, 2004.

PARIZA, M. W. et al. Effects of temperature and time on mutagen formation in pan-fried hamburger. Cancer Letter, v. 7, n. 2-3, p. 63, 1979.

PARIZA, M. W.; HARGRAVES, W. A. A beef-derived mutagenesis modulator inhibits initiation of mouse epidermal tumors by 7,12-dimethylbenz[a] anthracene. Carcinogenesis, v. 6, n. 4, p. 591, 1985.

PARODI, P. W. Conjugated octadecadienoic acids of milk fat. Journal of Dairy Science, v. 60, n. 10, p. 1550-1553, 1977.

REEVES, P. G.; NIELSEN, F. H.; FAHEY, G. C. JR. AIN-93 Purified diets for laboratory rodents: final report of the American Institute of Nutrition Ad Hoc Writing Committee on the Reformulation of the AIN-76A rodent diet. Journal of Nutrition, v. 123, n. 11, p. 1939-1951, 1993.

RISÉRUS, U. et al. Effects of cis-9, trans-11 conjugated linoleic acid supplementation on insulin sensitivity, lipid peroxidation, and proinflamatory markers in obese men. American Journal of Clinical Nutrition, v. 80, n. 2, p. 279-283, 2004.

SALAS-SALVADÓ, J.; MARQUEZ-SANDOVAL, F.; BULLÓ, M. Conjugated linoleic acid intake in humans: a systematic review focusing on its effects on body composition, glucose, and lipid metabolism. Critical Reviews in Food Science and Nutritio, v. 46, n. 6, p. 479-488, 2006.

SANTOS-ZAGO, L. F.; BOTElho, A. P.; OliveirA, A. C. Supplementation with commercial mixtures of conjugated linoleic acid in association with vitamin $\mathrm{E}$ and the process of lipid autoxidation in rats. Lipids, v. 42, n. 9, p. 845- 854, 2007.

SATO, S. Ultrastructural and morphometric studies of normal rat hepatocytes. Journal of Submicroscopic Cytology and Pathology, v. 36, n. 2, p. 131-140, 2004.

SEHAT, N. et al. Identification of conjugated linoleic acid isomers in cheese by gas chromatography, silver ion high performance liquid chromatography and mass spectral reconstructed ion profiles. Comparison of chromatographic elution sequences, Lipids, v. 33, n. 10, p. 963-971, 1998.

STATISTICAL ANALYSIS SYSTEM - SAS. Institute Project for Windows: User's guide: Statistics. Version 8.0. Cary: USA inst., 2003.

VIDELA, L. A. et al. Oxidative stress-related parameters in the liver of non-alcoholic fatty liver disease patients. Clinical Science, v. 106, n. 3, p. 261-268, 2004.

YAMASAKI, M. et al. Effect of Dietary Conjugated Linoleic Acid on Lipid Peroxidation and Histological Change in Rat Liver Tissues. Journal of Agriculture and Food Chemistry, v. 48, n. 12, p. 6367-6371, 2000. 